\title{
Analysis of Flavanoids in Flour and Biscuit based on Chayote
}

\author{
*Jamaludin M. Sakung, Sitti Rahmawati, Nursafitri \& Husnia Muhtar \\ Pendidikan Kimia/FKIP - Universitas Tadulako, Palu - Indonesia 94119 \\ Received 14 September 2020, Revised 20 October 2020, Accepted 17 November 2020 \\ doi: 10.22487/j24775185.2020.v9.i4.pp219-223
}

\begin{abstract}
Chayote-based flour and biscuits are the development of healthy food products that contain flavonoid compounds that can be used to protect and reduce skin damage to UV rays. This study aimed to determine the flavonoid content in chayote-based flour and biscuits using the AlCl method with a UV-Vis spectrophotometry at a wavelength of 520 and $700 \mathrm{~nm}$. The results obtained the flavonoid levels in chayote-based flour and biscuits of $0.325 \pm 0.011 \mathrm{mg} / \mathrm{L}$ and $0.117 \pm 0.023 \mathrm{mg} / \mathrm{L}$ or equivalent to $0.812 \pm 0.028 \mathrm{mg} / 100$ gram and $0.291 \pm 0.058$ $\mathrm{mg} / 100 \mathrm{gram}$. This study concluded that chayote-based flour and biscuits contained flavonoids can be used as a source of antioxidants and a source of beneficial nutrition.
\end{abstract}

Keywords: Flavonoids, food product, UV-Vis spectrophotometry

\section{Pendahuluan}

Flavonoid merupakan senyawa polifenol yang paling melimpah dalam asupan makanan dan banyak ditemukan dalam biji-bijian, sayuran, buahbuahan, dan produk olahannya seperti labu siam. Flavonoid berperan sebagai antioksidan, antipenuaan, dan anti Karsinogenik. Selain itu, berbagai monomer flavonoid telah dikembangkan secara aktif sebagai obat yang digunakan dalam pengendalian penyakit degeneratif dan memiliki efek positif pada kualitas hidup manusia (Qin, dkk, 2018). Flavonoid berperan sebagai antioksidan, sehingga dapat meningkatkan pemanfaatan oksigen dalam proses metabolisme tubuh, dilaporkan mengkonsumsi buah labu siam dapat memberikan efek terhadap pertumbuhan dan pemanfaatan giz. Flavonoid merupakan molekul yang paling banyak terkandung dalam tumbuhan alam, kandungan flavonoid dalam daun labu siam yakni $35,0 \mathrm{mg} / 10$ $\mathrm{g}$ bagian kering, dalam akar labu siam yakni 30,5 $\mathrm{mg} / 10 \mathrm{~g}$, dan dalam batang labu siam yakni 19,3 mg/10 g (Erawati, dkk, 2016; Sibi, dkk, 2013).

Studi epidemiologi dan eksperimental menunjukkan bahwa asupan tinggi flavonoid dari tanaman labu siam sangat berperan dalam menurunkan risiko kanker, penyakit jantung, dan stroke. Sangat sedikit analisis atau studi fitokimia merupakan tantangan langsung dalam mengkaji manfaat bahan alam dalam penanganan daerah bermasalah kesehatan (Fidrianny \& Hartati, 2016; Rosado-Pérez, dkk, 2019)

Kadar flavonoid yang tinggi pada labu siam dan peran senyawanya pada bidang kesehatan, menyebabkan labu siam sangat dianjurkan untuk dikonsumsi, namun ketersediaan yang cukup melimpah dan masa simpan yang begitu cepat maka perlu pengembangan produk berbasis labu siam. Penganekaragaman pangan terhadap labu siam perlu ditingkatkan yang merupakan sumber gizi pada produk pangan. Salah satu yang dapat dilakukan adalah pembuatan tepung dan biskuit berbasis labu siam yang dapat memberikan efek positif bagi kesehatan tubuh. Produk makanan sehat menunjukkan sifat farmakologis seperti aktivitas sitotoksik dan antikanker (Riviello-Flores dkk., 2018).

Biskuit merupakan salah satu produk olahan yang digemari oleh masyarakat. Bahan baku biskuit adalah tepung labu siam lalu ditambahkan dengan bahan tambahan lainnya untuk meningkatkan rasa pada biskuit. Namun kandungan serat pada biskuit berbahan baku tepung labu siam relatif rendah $( \pm 1 \mathrm{~g} / 100 \mathrm{~g})$. Kandungan serat 1,7 gram $/ 100$ gram daging buah labu siam dapat dijadikan alternatif bagi masyarakat yang gemar mengkonsumsi biskuit, produk makanan yang mengandung serat relatif tinggi akan memberi rasa kenyang sehingga menurunkan konsumsi makanan. Makanan dengan kandungan serat kasar yang tinggi sekaligus kalori rendah, kadar gula dan lemak rendah yang dapat membantu mengurangi terjadinya obesitas (Asmira \& Arza, 2015; Mudgil, dkk, 2017).

Biskuit dengan penambahan tepung labu siam berpotensi sebagai makanan fungsional. Hal ini atas dasar bahwa labu siam merupakan sumber senyawa bioaktif, dimana kandungan fenolik total yang tinggi, terutama jenis flavonoid. Oleh karena itu biskuit dari tepung labu siam harus diketahui

*Correspondence:

Jamaludin M. Sakung

e-mail: jamaludinsakung17@gmail.com

(c) 2020 the Author(s) retain the copyright of this article. This article is published under the terms of the Creative Commons Attribution License 4.0, which permits unrestricted non-commercial use, distribution, and reproduction in any medium, provided the original work is properly cited. 
kadar flavonoid sebagai bahan non farmakologi untuk memberikan alternatif pengobatan dalam pencegahan penyakit degeneratif.

\section{Metode}

Penelitian ini merupakan penelitian eksperimen yang dilakukan di Laboratorium Pendidikan Kimia Fakultas Keguruan dan Ilmu Pendidikan Universitas Tadulako untuk pembuatan tepung dan biskuit berbasis labu siam dan di Laboratorum Penelitian Fakultas Matematika dan Ilmu Pengetahuan Alam Universitas Tadulako untuk analisis flavonoid.

Alat yang digunakan dalam penelitian yaitu spektrofotometer UV-Vis, timbangan digital, kertas saring, vacum rotary evaporator, plat tetes , erlenmayer, corong pisah, neraca analitik, labu ukur, gelas kimia, gelas ukur, mixer, pipet tetes, batang pengaduk, corong, kertas saring, blender, pisau, sendok, pemanggang kue, cetakan kue, wadah, kompor gas, oven, neraca digital dan electromagnetic sieve shaker. Bahan yang digunakan yaitu sampel tepung labu siam (Sechium Edule) berbasis labu siam, biskuit berbasis labu siam, metanol, aquades, klorofom, larutan buffer $\mathrm{pH} 1$, $\mathrm{pH} 4.5$, Logam magnesium, $\mathrm{HCl}$ pekat etanol, tepung terigu, gula pasir, minyak goreng, vanili dan soda.

\section{Pembuatan Biskuit}

Tepung labu siam yang kering dicampurkan soda kue dan vanili bubuk, kemudian dikocok bersama gula dan telur sampai mengembang, serta menambahkan sedikit demi sedikit bahan kering tersebut aduk menggunakan spatula atau sendok tambahkan minyak goreng hingga tercampur merata. Adonan didiamkan selama $15-20$ menit lalu diletakan di plat oven, pada temperatur $160-175{ }^{\circ} \mathrm{C}$ selama $30-35$ menit, kemudian didinginkan dan biskuit labu siam siap dianalisis kandungan flavanoidnya.

\section{Kadar Flavanoid}

Senyawa flavonoid pada tepung dan biskuit berbasis labu siam diuji menggunakan spektrofotometer UV-Vis, kemudian ditentukan kadarnya menggunakan metode $\mathrm{pH}$ diferensial. Metode $\mathrm{pH}$ differensial dalam penentuan kadar flavonoid pada tepung dan biskuit berbasis labu siam diawali dengan membuat larutan $100 \mathrm{mg} / \mathrm{L}$ dari masing-masing sampel yang akan digunakan sebagai larutan uji. $1 \mathrm{~mL}$ larutan uji dimasukkan ke dalam 2 buah tabung reaksi per sampel. Kemudian masing-masing sampel dimasukkan $4 \mathrm{~mL}$ larutan buffer $\mathrm{pH} 1$ pada tabung reaksi 1 dan buffer $\mathrm{pH}$ 4,5 pada tabung reaksi 2 dengan perbandingan larutan sampel dan buffer 1:4. Lalu mengukur nilai absorbansi dari kedua tabung tersebut menggunakan spektrofotometri UV-Vis pada panjang gelombang berturut-turut $520 \mathrm{~nm}$ dan 700 nm. $\lambda=520 \mathrm{~nm}$ merupakan $\lambda$ maksimum untuk sianidin-3-glukosida, dan pengukuran sampel pada $\lambda=700 \mathrm{~nm}$ bertujuan untuk mengoreksi atau memeriksa kekeruhan yang ada dalam larutan yang dianalisis. Jika sampel benar-benar jernih maka absorbansi pada $\lambda=700 \mathrm{~nm}$ adalah nol.

\section{Teknik Analisis Data}

Kadar flavonoid dapat dihitung menggunakan rumus: Absorbansi $=[(\mathrm{A} 520-\mathrm{A} 700) \mathrm{pH} 1-(\mathrm{A} 520-$ A700) $\mathrm{pH} 4,5]$

Total Flavonoid $(m g / L)=\frac{A x M r \times 1000}{€ x b}$

dimana A adalah absorbansi; $€$ adalah absorpsivitas molar sianidin-3-glukosida $(26.900 \mathrm{~L} / \mathrm{molcm})$; b adalah lebar kuvet $(\mathrm{cm})$; $\mathrm{Mr}$ adalah berat molekul sianidin-3-glukosida $(449,2 \mathrm{~g} / \mathrm{mol}) ;$ dan 1000 adalah faktor konversi gram ke miligram.

Dari hasil pengukuran didapat data kadar flavonoid. Kemudian data ini diolah dengan menggunakan rumusan berikut:

$\mathrm{Y}=\frac{V \cdot x}{m}$

dimana $Y$ adalah kadar flavonoid yang setara dengan $100 \mathrm{~g}$; $\mathrm{x}$ adalah kadar total flavonoid; $\mathrm{m}$ adalah massa sampel; dan $\mathrm{V}$ adalah volume penetapan sampel.

\section{Hasil dan Pembahasan}

Hasil penelitian menunjukkan perbedaan yang signifikan $(p<0,05)$ kadar flavonoid pada tepung dan biskuit berbasis labu siam. kultivar yang diteliti. Kadar flavonoid dalam tepung dan biskuit berbasis labu siam dapat dihitung berdasarkan nilai

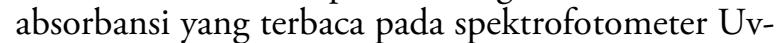
Vis panjang gelombang $700 \mathrm{~nm}$. Pada hasil perhitungan yang telah dilakukan didapatkan bahwa kadar flavonoid pada kedua bahan makanan berbasis labu siam sangat berbeda. Untuk tepung labu siam memilki kadar flavonoid sebesar 0,325 $\mathrm{mg} / \mathrm{L}$ dan untuk biskuit berbasis labu siam sebesar $0,117 \mathrm{mg} / \mathrm{L}$. Dari data tersebut dapat diketahui bahwa tepung labu siam memiliki kadar flavonoid terbesar dan biskuit berbasis labu siam memiliki kadar flavonoid yang paling sedikit. Hasil penelitian selanjutnya disajikan dalam Tabel 1 .

Tabel 1. Kadar flavonoid tepung dan biskuit berbasis labu siam

\begin{tabular}{lll}
\hline \multirow{2}{*}{ Replikasi } & \multicolumn{2}{l}{ Kadar flavonoid $(\mathrm{mg} / \mathrm{L})$} \\
\cline { 2 - 3 } & tepung & biskuit \\
\hline 1 & 0,317 & 0,100 \\
2 & 0,333 & 0,133 \\
(Rata-rata \pm SD) & $0,325 \pm 0,011$ & $0,117 \pm 0,023$ \\
\hline
\end{tabular}


Proses pengolahan suatu bahan makanan akan mempengaruhi kandungan gizi dan metabolik sekunder seperti halnya penelitian yang dilakukan oleh Soufi (2016) menyatakan pengolahan suatu bahan makanan menyebabkan penurunan kandungan flavonoid dari $22 \%$ hingga nilai ratarata 55. Penurunan kadar flavonoid karena terjadinya difusi dan proses oksidasi selama pengolahan dan penyimpanan (Alipour, dkk., 2016; Soufi, dkk, 2016). Penelitian Sibi (2013) menunjukkan bahwa flavonoid merupakan molekul yang paling banyak terkandung dalam tumbuhan alam, kandungan flavonoid dalam daun labu siam yakni 3,50 mg/100 g bagian kering, dalam akar labu siam yakni 3,05 mg/100 g, dan dalam batang labu siam yakni $1,93 \mathrm{mg} / 100 \mathrm{~g}$. Penurunan kadar flavonoid pada tepung labu siam menjadi 0,81 $\mathrm{mg} / 100 \mathrm{~g}$ dan biskuit berbasis labu siam menjadi $0,29 \mathrm{mg} / 100 \mathrm{~g}$.

Produk makanan olahan seperti biskuit memiliki bioaktifitas karena disebabkan oleh tingginya antioksidan, seperti senyawa fenolik dan flavonoid. Pemanasan dalam proses pembuatan produk makanan dapat menjaga kualitas makanan dari mikroorganisme, namun pada saat bersamaan merusak rasa alami dan komponen gizi dalam makanan (Tsai, dkk, 2018).

Tepung labu siam terdapat flavonoid 0,325 $\mathrm{mg} / \mathrm{L}$ yang artinya terdapat $0,325 \mathrm{mg}$ flavonoid dalam 1 Liter sampel dan pada biskuit berbasis labu siam terdapat flavonoid $0,117 \mathrm{mg} / \mathrm{L}$ yang artinya terdapat $0,117 \mathrm{mg}$ flavonoid dalam 1 Liter sampel.

Tepung dan biskuit berbasis labu siam dapat direkomendasikan sebagai makanan fungsional dengan kandungan flavonoid yang berguna bagi tubuh sebagai antioksidan. Senyawa metabolit sekunder terbanyak yang dikonsumsi manusia bersifat melawan radikal bebas, dan secara signifikan dapat menurunkan risiko penyakit tidak menular. Penelitian pada responden berusia $\geq 19$ tahun menunjukkan asupan flavonoid mampu menurunkan risiko kanker $41 \%$, penyakit jantung coroner $18 \%$, hipertensi $9 \%$, diabetes Mellitus $8 \%$, gagal jantung 19\%, dan stroke 10\% (Ayo, dkk, 2018; Cassidy, dkk., 2012; Fidrianny, dkk, 2015).

Tabel 1 menunjukkan penurunan kadar flavonoid pada biskuit berbasis labu siam, hal tersebut terjadi pada saat proses pemasakan biskuit dimana flavonoid menyerap kedalam air. Kadar flavonoid pada biskuit berbasis labus siam dapat dipertahankan dengan melakukan formulasi tepung labu siam dengan biji kacang hitam (Phaseolus vulgaris) yang tanpa mempengaruhi karakteristik produk makanan (Chávez-Santoscoy, dkk, 2016; Ramírez-Jiménez, dkk, 2014). Kadar flavonoid pada tepung lebih tinggi lebih kurang 3 kali lipat dari biskuit berbasis labu siam hal ini sejalan dengan penelitian Chlopicka (2012) melaporkan kandungan total flavonoid atau total flavonoid content (TFC) tepung kira-kira 2-4 kali lipat lebih tinggi dari pada biskuit. Mie dan biskuit kukus adalah produk berbasis tepung yang paling banyak dikonsumsi di Cina. Para peneliti telah fokus pada mie tepung dan kualitas produk makanan dengan kadar flavonoid dan informasi tentang sifat antioksidannya. (Chlopicka, dkk, 2012; Li, dkk., 2015; Shafie, 2019). Hasil penelitian GbengaFabusiwa (2018) mengungkapkan bahwa tepung kacang polong memiliki kandungan fenol dan flavonoid total yang lebih tinggi serta aktivitas antioksidan yang lebih tinggi daripada biskuit. Hasil ini menunjukkan bahwa tepung kacang polong dan biskuit dapat berfungsi sebagai makanan fungsional yang murah (Gbenga-Fabusiwa, dkk, 2018).

Biskuit adalah makanan dengan kadar air rendah dengan standar wajib kadar air terutama di bawah 6\%. Kelembaban biskuit relatif renda pada proses pemanggangan biskuit sehingga untuk mencegah penyerapan air yang cepat dari udara, selanjutnya untuk menjaga biskuit tahan uap air maka harus dikemas sehingga rentan terhadap serangan mikroba dan proses oksidatif karena lemak adalah bahan utama yang digunakan selama pembuatan biskuit. Bahan pengemasan adalah bahan dengan kriteria: tahan uap air, tidak mudah rusak atau cukup kuat, warna gelap dan mudah ternoda dengan ketahanan gemuk yang baik dan mudah dicetak (Canalis, dkk, 2019; Poudel, 2019).

Flavonoid yang terkandung pada labu siam dan pengembangan produk makanan berperan dalam menghambat regulasi sistem renin angiotensin aldosterone dan dapat menghambat angiotensin I converting enzyme (ACE). Peran ACE dalam pembentukan angiotensin II yang merupakan salah satu penyebab hipertensi. Angiotensin II menyebabkan pembuluh darah menyempit dan dapat menaikkan tekanan darah. ACE inhibitor menyebabkan pembuluh darah melebar sehingga darah lebih banyak mengalir ke jantung, mengakibatkan penurunan tekanan darah (Djaelani, 2015; Lombardo-Earl et al., 2014).

Selain itu, flavonoid dapat meningkatkan urinasi dan pengeluaran elektrolit, yang mana berfungsi layaknya kalium, yaitu mengabsorbsi cairan ion-ion elektrolit seperti natrium yang ada di dalam intraseluler darah untuk menuju ekstraseluler memasuki tubulus ginjal. Glomerular Filtration Rate (GFR) yang tinggi akibat adanya aktivitas flavonoid menyebabkan ginjal mampu mengeluarkan produk buangan dari tubuh dengan cepat. Tepung dan biskuit berbasis labu siam terdapat kalium yang tinggi selain flavonoid yang mempengaruhi pengeluaran urin yang dapat meningkatkan pengeluaran natrium, sehingga kadar natrium menurun dan mencegah hipertensi. (Mahdieh Golzarand, 2016; Sinaga, dkk, 2018).

Hasil flavonoid dalam tepung dan biskuit berbasis labu siam sebesar $0,81 \%$ dan $0,29 \%$, jika rata-rata asupan flavonoid sebesar 0,145 gram pada laki-laki dan 0,204 gram pada perempuan per hari, maka kadar flavonoid dalam tepung dan biskuit berbasis labu siam dapat memenuhi memenuhi flavonoid untuk laki-laki per dan perempuan, sehingga produk berbasis labu siam dapat digunakan sebagai alternative makanan fungsional. flavonoid dapat menghambat penyerapan glukosa 
dari ginjal dan hiperglikemia secara signifikan dapat menurun. (Isdamayani \& Panunggal, 2015).

Kebutuhan flavonoid dalam produk berbasis labu siam diharapkan berperan sebagai antioksidan sekunder pada penderita diabetes mellitus tipe 2. Peningkatan radikal bebas dan penekanan antioksidan enzimatik dapat menyebabakan stress oksidatif, sehingga tubuh perlu asupan antioksidan non enzimatik yang diperoleh dari produk makanan berbasis labu siam. Asupan antioksidan dari produk makanan dalam bentuk antioksidan sekunder yang bekerja memutuskan reaksi oksidasi dan menangkap radikal bebas (Fenton-Navarro, dkk, 2019; Sharma, dkk, 2018).

\section{Kesimpulan}

Tepung dan biskuit berbasis labu siam mengandung flavonoid $0,812 \mathrm{mg} / 100$ gram dan $0,291 \mathrm{mg} / 100 \mathrm{gram}$ yang dapat digunakan sebagai sumber antioksidan dan sumber nutrisi yang bermanfaat.

\section{Ucapan Terima Kasih}

Terima kasih penulis kepada Universitas Tadulako yang mendanai penelitian ini melalui dana DIPA FKIP Universitas Tadulako dan ditunjang oleh laboratorium pendidikan kimia FKIP dan laboratorium penelitian FMIPA universitas tadulako

\section{Referensi}

Alipour, B., Rashidkhani, B., \& Edalati, S. (2016). Dietary flavonoid intake, total antioxidant capacity and lipid oxidative damage: A crosssectional study of iranian women. Nutrition, 32(5), 566-572.

Asmira, S., \& Arza, P. A. (2015). Pengaruh penggunaan labu siam (sechium edule) dengan konsentrasi yang berbeda terhadap mutu organoleptik dan kadar serat kerupuk ikan. Jurnal Kesehatan Perintis, 2(2), 38-46.

Ayo, J., Ayo, V., \& Igweaka, C. (2018). Phytochemical, physicochemical and sensory quality of acha-orange peel flour blend biscuits. Production Agriculture and Technology, 14(1), 81-90.

Canalis, M. B., León, A., \& Ribotta, P. (2019). Incorporation of dietary fiber on the cookie dough. Effects on thermal properties and water availability. Food Chemistry, 271, 309317.

Cassidy, A., Rimm, E. B., O'Reilly, É. J., Logroscino, G., Kay, C., Chiuve, S. E., \& Rexrode, K. M. (2012). Dietary flavonoids and risk of stroke in women. Stroke, 43(4), 946-951.

Chávez-Santoscoy, R. A., Gutiérrez-Uribe, J. A., Serna-Saldivar, S. O., \& Perez-Carrillo, E.
(2016). Production of maize tortillas and cookies from nixtamalized flour enriched with anthocyanins, flavonoids and saponins extracted from black bean (phaseolus vulgaris) seed coats. Food Chemistry, 192, 9097.

Chlopicka, J., Pasko, P., Gorinstein, S., Jedryas, A., \& Zagrodzki, P. (2012). Total phenolic and total flavonoid content, antioxidant activity and sensory evaluation of pseudocereal breads. LWT-Food Science and Technology, $46(2), 548-555$.

Djaelani, E. K. P. (2015). Pengaruh sari buah labu siam terhadap perubahan tekanan darah pada lansia penderita hipertensi di pstw budhi luhur kasongan bantul yogyakarta. Yogyakarta: STIKES'Aisyiyah Yogyakarta.

Erawati, E., Pratiwi, D., \& Zaky, M. (2016). Pengembangan formulasi dan evaluasi fisik sediaan krim ekstrak etanol 70\% daun labu siam (sechium edule (jacq.) swatz). Jurnal Farmagazine, 3(1), 11-19.

Fenton-Navarro, B., Montes, F. O., \& Hernández, A. V. (2019). Active compounds of medicinal plants, mechanism for antioxidant and beneficial effects. Phyton, International Journal of Experimental Botany, 88(1), 1-10.

Fidrianny, I., Ayu, D., \& Hartati, R. (2015). Antioxidant capacities, phenolic, flavonoid and carotenoid content of various polarities extracts from three organs of Sechium edule (Jacq.) Swartz. Journal of Chemical and Pharmaceutical Research, 7(5), 914-920.

Fidrianny, I. K., \& Hartati. R. (2016). Evaluation of antioxidant activities of fruit extracts of chayote (sechium edule [jacq.] swartz) grown in different sites in java-Indonesia. Evaluation, 9(4).

Gbenga-Fabusiwa, F. J., Oladele, E. P., Oboh, G., Adefegha, S. A., \& Oshodi, A. A. (2018). Polyphenol contents and antioxidants activities of biscuits produced from gingerenriched pigeon pea-wheat composite flour blends. Journal of Food Biochemistry, 42(4). e12526.

Isdamayani, L., \& Panunggal, B. (2015). Kandungan flavonoid, total fenol, dan antioksidan snack bar sorgum sebagai alternatif makanan selingan penderita diabetes mellitus tipe 2. Journal of Nutrition College, 4(2), 342-349.

Li, Y., Ma, D., Sun, D., Wang, C., Zhang, J., Xie, Y., \& Guo, T. (2015). Total phenolic, flavonoid content, and antioxidant activity of flour, noodles, and steamed bread made from different colored wheat grains by three milling methods. The Crop Journal, 3(4), 328-334. 
Lombardo-Earl, G., Roman-Ramos, R., Zamilpa, A., Herrera-Ruiz, M., Rosas-Salgado, G., Tortoriello, J., \& Jiménez-Ferrer, E. (2014). Extracts and fractions from edible roots of sechium edule (Jacq.) Sw. with antihypertensive activity. Evidence-Based Complementary and Alternative Medicine, 19.

Mahdieh, G, Z. B., Mirmiran, P., Vakili, A. Z., \& Azizi. F. (2016). Consumption of nitratecontaining vegetables is inversely associated with hypertension in adults: A prospective investigation from the Tehran lipid and glucose study. Journal of Nephrology, 29(3), 377-384

Mudgil, D., Barak, S., \& Khatkar, B. (2017). Cookie texture, spread ratio and sensory acceptability of cookies as a function of soluble dietary fiber, baking time and different water levels. LWT-Food Science and Technology, 80(1), 537-542.

Poudel, A. R. (2019). Preparation and quality evaluation of buckwheat flour incorporated biscuit. Institute of Science and Technology Food Technology Instruction Committee

Qin, X., Lu, Y., Peng, Z., Fan, S., \& Yao, Y. (2018). Systematic chemical analysis approach reveals superior antioxidant capacity via the synergistic effect of flavonoid compounds in red vegetative tissues. Frontiers in Chemistry, 6, 9.

Ramírez-Jiménez, A., Reynoso-Camacho, R., Mendoza-Díaz, S., \& Loarca-Piña, G. (2014). Functional and technological potential of dehydrated phaseolus vulgaris $\mathrm{L}$. flours. Food Chemistry, 161, 254-260.

Riviello-Flores, M., Arévalo-Galarza, M., CadenaIńiguez, J., Soto-Hernández, R., RuizPosadas, L., \& Gómez-Merino, F. (2018). Nutraceutic characteristics of the extracts and juice of chayote (sechium edule (jacq.) sw.) fruits. Beverages, 4(2), 1-11.
Rosado-Pérez, J., Aguiñiga-Sánchez, I., SantiagoOsorio, E., \& Mendoza-Núñez, V. M. (2019). Effect of sechium edule var. nigrum spinosum (chayote) on oxidative stress and pro-inflammatory markers in older adults with metabolic syndrome: An exploratory study. Antioxidants, 8(5), 1-10.

Shafie, S. R. (2019). Nutritional composition, total phenolic content and total flavonoid content of wheat bread and quinoa-wheat composite bread. Asia Pacific Environmental and Occupational Health Journal, 5(3), 16-21.

Sharma, G. N., Gupta, G., \& Sharma, P. (2018). A comprehensive review of free radicals, antioxidants, and their relationship with human ailments. Critical Reviews ${ }^{\mathrm{TM}}$ in Eukaryotic Gene Expression, 28(2), 139-154.

Sibi, G., Kaushik, K., Dhananjaya, K., Ravikumar, K., \& Mallesha, H. (2013). Antibacterial activity of sechium edule (Jacq.) swartz against gram negative food borne bacteria. Advances in Applied Science Research, 4(2), 259-261.

Sinaga, S. M., Iksen, I., Haro, G., \& Wardhany, S. (2018). Potency of chives (allium schoenoprasum 1.) leaves infuse as inhibitor calcium lithogenesis on urinary tract. Asian Journal of Pharmaceutical Clinical Research, 11(3), 77-80.

Soufi, O., Romero, C., Motilva Casado, M., Borrás Gaya, X., \& Louaileche, H. (2016). Effect of dry salting on flavonoid profile and antioxidant capacity of algerian olive cultivars. Grasas y Aceites, 67(2), 1-9.

Tsai, M. J., Cheng, M. C., Chen, B. Y., \& Wang, C. Y. (2018). Effect of high-pressure processing on immunoreactivity, microbial and physicochemical properties of hazelnut milk. International Journal of Food Science \& Technology, 53(7), 1672-1680. 